\title{
Impact of Academic and Social Factors on Education Performance of Students
}

\author{
Rahul Chauhan ${ }^{1}$, Bhoomi R. Chauhan ${ }^{2}$ \\ ${ }^{1}$ Assistant Professor, Parul Institute of Business Administration, Parul University, Baroda \\ ${ }^{2}$ Assistant Professor, Parul Institute of Nursing, Parul University, Baroda
}

Email:rj88chauhan@gmail.com,chauhan@yahoo.in

\begin{abstract}
Counseling makes perfect any human being for living life smoothly. According to phycology people required someone near to him/her with whom he/she can share their thoughts, happiness, emotions etc. and this is required in education also, In education we need to give support to our students for knowing their problems and feeling regarding education, life, career, friends, family etc. in this paper researcher tried to find out the importance of the counseling in the mind of students of the effect of the same in students mind because in the recent time importance of the education is more and the use of technology is also more so its big problem for the students for connecting consciously with the learning, and without consciousness people cannot understand many thinks for life long time it's just for examination. By using the qualitative research study research has tried to find out solution for the same with the sample of 60 students of undergraduate of Parul University. During the research researcher identified major two internal and external factors in which there are six other factors, with the help of the qualitative research technique.
\end{abstract}

Keywords: Counseling, Education Performance, Students Mind.

\section{INTRODUCTION}

Education is the important for making any nation great. With the help of the education university and teacher can create a good outcome for the student's life and supporting system for life of students. As per psychology one person cannot speak friendly with other unknown person, even if it's his/her teacher of professor. Effective college counseling services today include extensive students outreach, deep integration with the institution's academic mission, and evidence of contribution to student academic success (Archer \& Cooper, 1998; Davis \& Humphrey, 2000). Counseling is also help full for student retention in study. One of the ways in which counseling services can better assist colleges and universities in meeting their aims is through prevention initiatives designed to enhance the retention of students. Student retention is a long-standing challenge that institutions continue to address (Braxton, Bray, \& Berger, 2000). Research has found that retention rates increase when students are academically and socially integrated into the university or college environment, when they have positive regard for their academic performance, and when they value the supportive relationships they have established at the institution (Pascarella \& Terenzini, 1983, 1991) by this literature researcher can say that through the counseling universities can increase the performance of the academic outcome and the retention in the continuous study and also helps to reduce the drop out ration which is the bigger problem now a days for the universities and colleges.

One of the effect is reduction in the students drop out ration, Interactions between individuals and the academic system, along with social interactions, continually modify goals and institutional commitments in ways that lead to persistence or to varying forms of dropout (Stage, 1989; Tinto, 1993). Academically students are enrolled with the institute or universities but the socially they want someone for sharing their feeling and problems just like after parents they are having second trust on the teacher or the professor. 


\section{LITERATURE REVIEW}

Counseling of College Students must consider each student's unique inventory and provide individualized programming focused on student growth and development. Recognizing this, (Pascarella and Terenzini 1991) asserted that effective higher education embraces "the broader mission[that] has defined education to include increased self-understanding, and expansion of personal, intellectual, cultural, and social horizons and interests"

Archer and Cooper (1998) noted that one of the greatest challenges for college counseling is to provide integrated and coordinated services that successfully mesh with academic goals. Archer and Cooper also believed that the potential of counseling services would be more fully realized if programs became more fully integrated into the academic mission of the institution. Ironically, this integration is often overlooked in the implementation and evaluation of student services programs ( Elkins, Braxton, \& James, 1998; Phillips-Miller \& Morrison, 1999)

Curricular and co-curricular engagement strategies for promoting innovation have proliferated, efforts aimed at studying the effectiveness of such experiences have lagged behind substantially (Antal, Kingma, Moore, \& Streeter, 2014). As a recent headline in The Chronicle of Higher Education blared: "Colleges Have Spent Big Money on Innovation Centers. Do They Work?" (Wyllie,2018). This notable lack of evaluative efforts has plagued both traditional programming (e.g., entrepreneurship courses) and newer, more broadly accessible introductions of innovation in the curriculum. Common reasons cited for the persistence of this gap between pedagogical advances and their assessment range from a lack of measures that meaningfully align stated curricular priorities with quantifiable outcomes (DuvalCouetil,2013) to inadequate research designs that evaluate the efficacy of course taking related to innovation on aligned outcomes of interest (Antal et al.,2014).

\subsection{Keganian Perspectives}

Throughout his theoretical efforts to understand human developmental processes, Kegan (1982, 1994) hypothesized that an individual's progression toward more advanced orders of self might follow three interrelated lines of development: cognitive, social, and intrapersonal. To briefly summarize: Cognitive development is concerned with those mechanisms by which we reason and interpret information and processes occurring in the world around us; social development is concerned with relationships between ourselves and others; and intrapersonal development is concerned with the mechanisms by which we engage in self-reflection and achieve increasing

degrees of self-understanding (Kegan, 1994).

As innovation and its manifestations necessarily involve the whole person (see James \& Brookfield, 2014; Morris, Webb, Fu, \& Singhal, 2013; Wagner, 2012), we adopted a Keganian-oriented approach to framing those intrapersonal, social, and cognitive aspects of self that could be developed in association with innovation - their innovation capacities. A detailed review of the literature (Selznick, 2017) suggested that any investigation of intrapersonal aspects should include a student's sense of himself or herself as being an intrinsically motivated, proactive innovator (Barbosa, Gerhardt, \& Kickul, 2007; Kickul, Gundry, Barbosa, \& Whitcanack, 2009; Wagner, 2012). Turning to social aspects, literature across disciplines has suggested the vital importance of educational efforts in building students' skills to persuasively communicate with team members and build sustaining interdisciplinary peer and near-peer networks (Boyles, 2012; Poysa-Tarhonnen, Elen, \& Tarhonen, 2016; Shane, 2003). Creative cognition and intellectual risk taking were central elements with respect to the cognitive domain. Drawing on (Koestler's 1964) theoretical work, creative cognition was considered to be a cognitive ability associated with generating novel ideas that frequently bridge gaps between knowledge across differing domains, types, and contexts (Dubitzky, Kotter, Schmidt, \& Berthold, 2012; Hulme, Thomas, \& DeLaRosby, 2014; Koestler, 1964; Morris et al., 2013; Phillips, 2013). Intriguingly, recent work on creative cognition has suggested that pedagogies that engage students in unfamiliar and imaginative approaches to new material can inspire moments of "helpful creative panic" that excite learners and spark innovation (James \& Brookfield, 2014, p. 10; see also Barbosa et al., 2007; Poysa-Tarhonnen et al., 2016).

\subsection{Theory of Planned Behavior}

To supplement Kegan's developmental approaches and in line with several studies that have approached innovation and its connections to formal entrepreneurship (e.g., Moriano et al., 2012), we also incorporated Ajzen's $(1991,2002)$ planned behavioral perspective to more fully understand the influence 
of curricular interventions on spurring innovation behavior during and after college. In brief, this theoretical presentation hypothesized that actions individuals believe are favorable, socially desirable, and achievable are those most likely happen (Ajzen, 2002).

Applying this framework to research, a sustained line of inquiry has sought to understand the relationship between educational experiences and an individual's expressed intentions to engage in innovation and/or entrepreneurship (Bae, Qian, Miao, \& Fiet, 2014; Bagheri \& Pihie, 2014; Souitaris, Zerbinati, \& Al-Laham, 2007; Zhao, Seibert, \& Hills, 2005). To better understand the extent to which a broad pattern of effectiveness in developing this outcome might exist, a recent meta-analysis (Bae et al., 2014) examined 73 studies that sought to determine the relationship between entrepreneurship education interventions and the appearance of entrepreneurial intentions. Findings demonstrated that dedicated entrepreneurship education had a significant, positive relationship with intentions (Bae et al., 2014, p. 239).

\section{OBJECTIVE}

Objective of this paper is to study the behavior of the students of the BBA who average age is 19 years and the effect of connectivity of the students in academic as well as the socially with the academic institute. And there are various factors which directly affected to the student mind and the counseling of the students, like the environment during counseling, question pattern, effect of the table between the students and professor during the counseling, area of the counseling. Study and the career is also important for students so also researcher can find out the effect of the counseling and other activities on the students own life with the help of the qualitative research instruments and duration of the study includes the asking the same every after the 4-5 months. So we can analyze the data frequently and also researcher can evaluate the performance of the same.

\section{RESEARCH METHODOLOGY}

The primary measure used for this study was a theoretically supported reliable and valid instrument designed to assess students' innovation capacities (see Selznick \& Mayhew, 2018). The innovation capacity scores were second-order factor scores calculated from nine conditioned constructs, including intrinsic motivation, proactivity, innovation self-concept, networking, persuasive communication, teamwork across difference, creative cognition, intention to innovate, and risk taking/tolerance. Intrinsic motivation, proactivity, and innovation self-concept represent the intrapersonal dimension of the innovation capacity.

Intrinsic motivation measures confidence in one's ability to stay motivated when working toward achieving goals; proactivity measures confidence in one's ability to gather information and resources required realizing objectives; and innovation self-concept measures the perception of oneself as someone who can be innovative.

The social dimension of the innovation capacity includes networking, persuasive communication, and teamwork across differences. Networking measures one's comfort with developing and sustaining mutually beneficial new relationships; persuasive communication measures perceived effectiveness in one's ability to clearly communicate new ideas and action plans to others; and teamwork across differences measures perceived effectiveness in one's ability to work as part of a group consisting of diverse others to achieve a common objective. (Matthew J. Mayhew, Benjamin S. Selznick, Lini Zhang, Amy C. Barnes \& B. Ashley Staples, 2018) in this study researcher used the primary data collection by the in-depth interview or counseling with the total 60 students of the BBA Class of Parul University. With the every student research sped more than 15 minute for knowing well to the background of the students.

\section{ANALYSIS}

This study is fully based on the qualitative research methods so researcher has taken the interview of response from the students of under graduate students of Parul University, Management department with the help of the structured question and the question based on the response of the students and following outcome was measured. As this study is continuous researcher has just identifies the single 
time information from the students and more will come after completion of the research of two years. In primary stage we found the following facts and information and problems faced by the students during the counseling and discussion. The quality of students' performance remains at top priority for educators. It is meant for making a difference locally, regionally, nationally and globally. Educators, trainers, and researchers have long been interested in exploring variables contributing effectively for quality of performance of learners. These variables are inside and outside school that affect students' quality of academic achievement. These factors may be termed as student factors, family factors, school factors and peer factors (Crosnoe, Johnson \& Elder, 2004).

Besides other factors, socioeconomic status is one of the most researched and debated factor among educational professionals that contribute towards the academic performance of students. The most prevalent argument is that the socioeconomic status of learners affects the quality of their academic performance. Most of the experts argue that the low socioeconomic status has negative effect on the academic performance of students because the basic needs of students remain unfulfilled and hence they do not perform better academically (Adams, 1996). Gender, ethnicity, and father's occupation are significant contributors to student achievement (McCoy, 2005; Peng \& Hall, 1995).

Theory of Educational Productivity by Walberg (1981) determined three groups of nine factors based on affective, cognitive and behavioral skills for optimization of learning that affect the quality of academic performance: Aptitude (ability, development and motivation); instruction (amount and quality); environment (home, classroom, peers and television) (Roberts, 2007).

In this research following six factors we can consider for the research as researcher identified during the first phase of counseling

\subsection{Internal Factors at College Level}

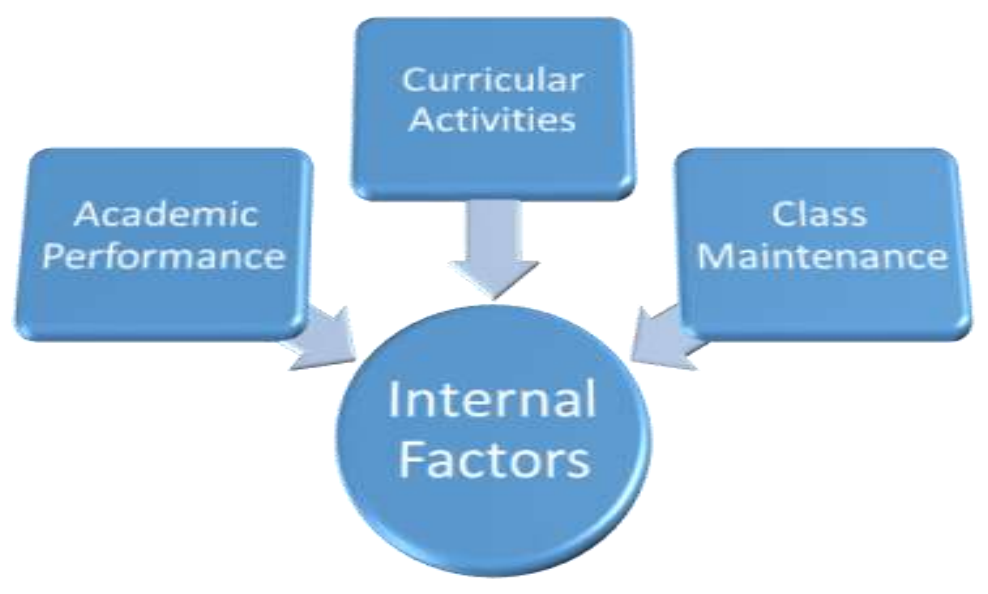

In this paper research has just identified the various factors which are highly affected the academic performance of the student. That includes in above chart.

\subsubsection{Academic Performance}

During the counseling in the first phase researcher identified one of the factor that is the past academic performance of the students. Past performance plays a very effective role in the life of the students. There are mainly three types of the performance of the students in past which are as follows: 1. Very Good, 2. Average, 3. Poor Performance

According to this study we can solve above problem by following ways

\begin{tabular}{|c|c|c|c|}
\hline No. & Parameter & Negative effect & Counseling effect \\
\hline 1 & Very Good & $\begin{array}{l}\text { If past performance is very } \\
\text { good or we can say positive } \\
\text { than its possible in the under } \\
\text { graduate or post graduate the }\end{array}$ & $\begin{array}{l}\text { If we are providing the } \\
\text { types of the students than it } \\
\text { may happened the results of }\end{array}$ \\
\hline
\end{tabular}




\begin{tabular}{|c|c|c|c|}
\hline & & $\begin{array}{l}\text { performance of the students } \\
\text { may decreased because of the } \\
\text { high positive thoughts of the } \\
\text { students. } \\
\text { Effect : mostly result } \\
\text { decreased }\end{array}$ & $\begin{array}{l}\text { the students not deceased by } \\
\text { they can maintain during the } \\
5 \text { to } 6 \text { years in UG and PG } \\
\text { courses. } \\
\text { Effect : Positive Outcome }\end{array}$ \\
\hline 2 & Average & $\begin{array}{l}\text { Here average results means } \\
\text { not fail in any subject but } \\
\text { below the } 65 \% \text { or } 55 \% \text {. } \\
\text { Average result in the past } \\
\text { records shows the effect of } \\
\text { the mind during the class } \\
\text { room lectures of the students } \\
\text { mostly. In some of the case it } \\
\text { may happened by the } \\
\text { personal reason. } \\
\text { Effect : may be again below } \\
\text { the line }\end{array}$ & $\begin{array}{l}\text { Proper guidance to one to one } \\
\text { student will help to improve } \\
\text { the performance of the } \\
\text { outcome and increased the } \\
\text { total understanding power of } \\
\text { the students. As a result the } \\
\text { students thinking ability will } \\
\text { become active } \\
\text { Effect : average to positive } \\
\text { increased result }\end{array}$ \\
\hline 3 & Poor Performance & $\begin{array}{l}\text { Past Poor performance } \\
\text { indicate the interest of the } \\
\text { students. It may be possible } \\
\text { that are having the interest in } \\
\text { other activities and they are } \\
\text { studying force fully, and also } \\
\text { non activeness of mind. } \\
\text { Effect: again poor result in } \\
\text { UG and PG and failure in the } \\
\text { career if due to force for } \\
\text { study and is in other activity } \\
\text { interest than they may start } \\
\text { they own career after study. }\end{array}$ & $\begin{array}{l}\text { More counseling is required } \\
\text { at this time because the } \\
\text { chances of suicide are more } \\
\text { because of the failure in } \\
\text { academic performance and } \\
\text { negative image in the society. } \\
\text { In this situation more } \\
\text { frequently counseling is } \\
\text { required and development of } \\
\text { more understanding power is } \\
\text { required. Activities for } \\
\text { making active mind are } \\
\text { required. } \\
\text { Effect : proper effective } \\
\text { counseling make students } \\
\text { active and perfect }\end{array}$ \\
\hline
\end{tabular}

\subsubsection{Curricular Activities and Cultural Performance}

In the UC course, curricular activities plays importance role for increasing the effectiveness of the mind and activeness of mind, during the school level the mind is not matured and not that much active for thinking beyond the limit but in UG course the activeness of mind is more required because the it is the stage where he/she can develop their own way for career development. They are thinking regarding the self-motivation and self-actualization requirement. For this cultural and curricular activities are more effective. According to our research students more respond to add sports activities, Dancing, Drawing, Singing and Game planning, these will help to active the mind of the students. Mind required more counseling during the age of 18 to 20 regarding career. 


\subsubsection{Class Maintenances}

Class Maintenance include the class overall management which includes the cleanness of classroom, overall management of classroom, environment of classroom, discipline during the lecture etc.. Which are described in following table.

\begin{tabular}{|c|c|c|}
\hline No. & Classroom Maintenance & Effect \\
\hline 1 & Cleanness of Classroom & $\begin{array}{l}\text { Cleanness of classroom plays a vary importance role } \\
\text { in the mind of the students, because for the study } \\
\text { unclear classroom. If class room is not clear properly } \\
\text { than students are thinking more about the cleanness } \\
\text { of classroom rather than the study. } \\
\text { Solution : clean classroom }\end{array}$ \\
\hline 2 & Overall management & $\begin{array}{l}\text { Overall management includes the class } \\
\text { representative behavior, class room structure, and } \\
\text { photos which are on the wall of the classroom. } \\
\text { Effective and motivated images on the wall of the } \\
\text { classroom plays important role in the classroom } \\
\text { Solution: one notice board required, use } \\
\text { motivational quotes in classroom notice board, and } \\
\text { make every think clear from management side. }\end{array}$ \\
\hline 3 & Environment of Classroom & $\begin{array}{l}\text { Environment of classroom includes the ventilation in } \\
\text { the classroom and overall the temperature of the } \\
\text { classroom during all the year. } \\
\text { Solution: use proper structured classroom. }\end{array}$ \\
\hline 4 & $\begin{array}{c}\text { Discipline Level during } \\
\text { Lecture }\end{array}$ & $\begin{array}{l}\text { Discipline during the lecture again plays important } \\
\text { role because every lecture and every point of lecture } \\
\text { is connected with each other so during the lecture if } \\
\text { discipline is not maintained than its very difficult to } \\
\text { solve this situation. So students' behavior is plays } \\
\text { important role here. } \\
\text { Solution : try to maintain discipline during the } \\
\text { lecture }\end{array}$ \\
\hline 5 & Seating Arrangement & $\begin{array}{l}\text { Seating arrangement is also plays important role in } \\
\text { the mind of the students. If seating is more congested } \\
\text { or too much students in one class with less number } \\
\text { of benches refers to the improper management from } \\
\text { the management of academic institute and it leads to } \\
\text { the negative image of the institution in the mind of } \\
\text { the students. } \\
\text { Solution: make everything in proper way and } \\
\text { according to the present situation. }\end{array}$ \\
\hline 6 & Regular Attendance & $\begin{array}{l}\text { Regular attendance of the students also plays } \\
\text { important role in the other students mind because if } \\
\text { everyone not coming in class, others may think } \\
\text { nothing is going important in classroom but if }\end{array}$ \\
\hline
\end{tabular}




\begin{tabular}{|l|l|l|}
\hline & $\begin{array}{l}\text { everyone coming in the class than they may feel } \\
\text { something is going very important in the class so } \\
\text { they may also come for attending class. }\end{array}$ \\
$\begin{array}{l}\text { Solution: increase attendance of the classroom } \\
\text { regular basis. }\end{array}$ \\
\hline
\end{tabular}

So according to this research in classroom above all factors affect during the teaching and improvement is required in all the factors. In this research above all factors research found during the interview of students.

\subsection{External Factors at College Level}

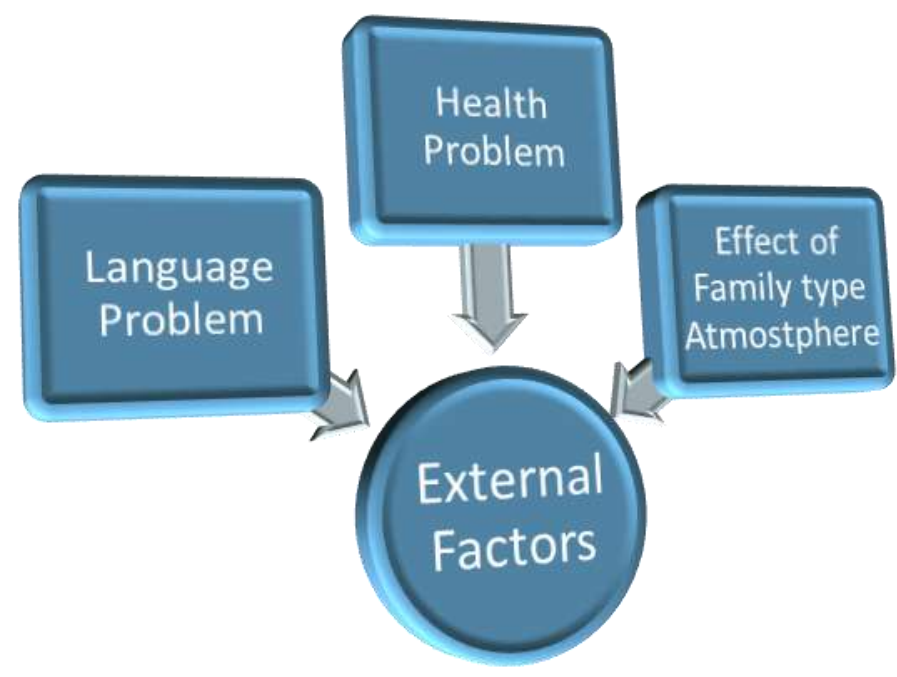

\subsection{Language Problem}

Language is the problem for the new students who are not from the course medium because they are not able to understand proper course in the course language. For example in Gujarat, Gujarati is the very common language so if someone takes admission in BBA or MBA they might face the problem due to the language issue. Same way south Indian students also face problem in the language. By this problem there are two effects: either they drop course or proper counseling may help them for the continuation of the course.

\begin{tabular}{|c|c|l|}
\hline No. & Language Problem & \multicolumn{1}{c|}{ Effect on students mind } \\
\hline 1 & Yes & $\begin{array}{l}\text { If students are facing problem for language during the UG and PG } \\
\text { Course, then may be negative effects may be come in the mind of the } \\
\text { student of they can quite the course. }\end{array}$ \\
\hline 2 & No & $\begin{array}{l}\text { If students not have any problem with the language than its good but } \\
\text { in this case we need to try increase the vocabulary of students. }\end{array}$ \\
\hline
\end{tabular}

\subsection{Health Problem}

Many times the students are having the health problem either temporary of may be for he lifetime. In that situation we need to do proper counseling because in one case due to the health issue one students drop the course. So during the counseling we need to ask is there any health issue of not if he/she having the health issue we need to identify proper treatment for the same or else any emergency medicine always keep in our department.

\begin{tabular}{|l|l|l|l|}
\hline $\begin{array}{l}\text { If health issue with the } \\
\text { students }\end{array}$ & $\begin{array}{l}\text { Try to counsel them proper and } \\
\text { identity proper reason }\end{array}$ & $\begin{array}{l}\text { Try to identify the proper } \\
\text { medicine for the emergency. }\end{array}$ \\
\hline
\end{tabular}




\subsection{Family atmosphere in campus}

Students are spending more time in college campus so they are feeling like college is second home for them, so we always need to take care of our students as like the parents. Family atmosphere gives them the proper situation for the learning and help them to identify future goal. For this proper counseling is required as like their brother or sister. This will help for overall increment in output. Parents' education level, parental profession, language, income and religious affiliations. These are usually discussed under the umbrella of demography (Ballatine, 1993). The home environment also affects the academic performance of students. Educated parents can provide such an environment that suits best for academic success of their children. The school authorities can provide counseling and guidance to parents for creating positive home environment for improvement in students' quality of work (Marzano, 2003). The academic performance of students heavily depends upon the parental involvement in their academic activities to attain the higher level of quality in academic success (Barnard, 2004; Henderson, 1988; Shumox \& Lomax, 2001).

\section{CONCLUSIONS}

As per this research paper researcher can conclude impact of the academic factors like academic performance, curricular activities and the class maintenance are high on the mind of the students and as academician we have to work on these factors more. On the other side, social factors which we are ignoring that are also important for the increasing the students' performance. Research is conducted of 60 students with the help of the qualitative research design and researcher found the above data during the first time counseling of the students.

In case of the academic factors we need to check first academic performance and background of the students first after that we need to take step according to the result. In case of the second factor that is curricular activities, every institute must arrange at least eight to ten activities during the one year for the mind activeness and classroom must be well maintained.

Influence of social factor is must for the archiving the academic factors. Social factors are attached emotionally with the mind of the students so if we are successfully taking care about the social factors then academic goal will be fulfilled automatically.

\section{REFERENCES}

1. Adams, A. (1996). Even basic needs of young are not met. Retrieved from http://tc.education. pitt.edu/library/SelfEsteem

2. Ajzen, I. (1991). The theory of planned behavior. Organizational Behavior and Human Decision Processes, 50, 179-211. doi:10.1016/0749-5978(91)90020-T

3. Ajzen, I. (2002). Perceived behavioral control, self-efficacy, locus of control, and the theory of planned behavior. Journal of Applied Social Psychology, 32, 1-20. doi:10.1111/j.15591816.2002. tb00236.x

4. Antal, N., Kingma, B., Moore, D., \& Streeter, D. (2014). University-wide entrepreneurship education. Advances in the Study of Entrepreneurship, Innovation and Economic Growth, 24, 227-254.

5. Archer, J., Jr., \& Cooper, S. (1998). Counseling and mental health services on campus: A handbook of contemporary practices and challenges. San Francisco: Jossey-Bass.

6. Bae, T. J., Qian, S., Miao, C., \& Fiet, J. O. (2014). The relationship between entrepreneurship education and entrepreneurial intentions: A meta-analytic review. Entrepreneurship Theory and Practice, 38(2), 217-254. doi:10.1111/etap.2014.38.issue-2

7. Bagheri, A., \& Pihie, Z. A. L. (2014). The factors shaping entrepreneurial intentions. Newcastle upon Tyne, England: Cambridge Scholars.

8. Ballatine, J. H. (1993). The sociology of education: A systematic analysis. Englwood Cliffs: Prentice Hall.

9. Barbosa, S. D., Gerhardt, M. W., \& Kickul, J. R. (2007). The role of cognitive style and risk preference on entrepreneurial self-efficacy and entrepreneurial intentions. Journal of Leadership and Organizational Studies, 13(4), 86-104. doi:10.1177/10717919070130041001 
10. Barnard, W. M. (2004). Parent involvement in elementary school and educational attainment . Children and Youth Services Review, 26, 39- 62.

11. Boyles, T. (2012). 21st century knowledge, skills, and abilities and entrepreneurial competencies: A model for undergraduate entrepreneurship education. Journal of Entrepreneurship Education, 15, 41-55.

12. Braxton, J. M., Bray, N. J., \& Berger, J. P. (2000). Faculty teaching skills and their influence on the college student departure process. Journal of College Student Development, 41, 2 15-227.

13. Ceballo, R., McLoyd, V., \& Toyokawa, T. (2004). The influence of neighborhood quality on adolescents' educational values and school efforts. Journal of Adolescent Research, 19(6), 716739.

14. Davis, C. D., \& Humphrey, K. M. (2000). College counseling: Issues and strategies for a new millennium. Alexandria, VA: American Counseling Association.

15. Dubitzky, W., Kotter, T., Schmidt, O., \& Berthold, M. R. (2012). Towards creative information exploration based on Koestler's concept of bisociation. In M. R. Berthold (Ed.),Bisociative knowledge discovery: An introduction to concept, algorithms, tools, and applications (pp. 1132). Berlin, Germnay: Springer-Verlag.

16. Duval-Couetil, N. (2013). Assessing the impact of entrepreneurship education programs: Challenges and approaches. Journal of Small Business Management, 51(3), 394-409. doi:10.1111/jsbm.12024

17. Hulme, E., Thomas, B., \& DeLaRosby, H. (2014). Developing creativity ecosystems: Preparing college students for tomorrow's innovation challenge. About Campus, 19(1), 14-23. doi:10.1002/abc.2014.19.issue-1

18. James, A., \& Brookfield, S. D. (2014). Engaging imagination: Helping students become creative and reflective thinkers. San Francisco, CA: Jossey Bass.

19. Kegan, R. (1982). The evolving self: Problem and process in human development. Cambridge, MA: Harvard University Press.

20. Kegan, R. (1994). In over our heads: The mental demands of modern life. Cambridge, MA: Harvard University Press.

21. Kickul, J, Gundry, L. K, Barbosa, S. D, \& Whitcanack, L. (2009). Intuition versus analysis? Testing differential models of cognitive style on entrepreneurial self-efficacy and the new venture creation process. Entrepreneurship Theory and Practice, 33(2), 439-453. doi:10.1111/etap.2009.33.issue-2

22. Koestler, A. (1964). The act of creation. New York, NY: Macmillan.

23. Marzano, R. J. (2003). What works in schools: Translating research into action? Retrieved from http://pdonline.ascd.org/pd_online/whatworks/marzano2003_ch13 .html

24. Matthew J. Mayhew, Benjamin S. Selznick, Lini Zhang, Amy C. Barnes \& B. Ashley Staples (2018): Examining Curricular Approaches to Developing Undergraduates' Innovation Capacities, The Journal of Higher Education, DOI: 10.1080/00221546.2018.1513307

25. McCoy, L. P. (2005). Effect of demographic and personal variables on achievement in eighth grade algebra. Journal of Educational Research, 98 (3), 131-135.

26. Moriano, J. A., Gorgievski, M., Laguna, M., Stephan, U., \& Zarafshani, K. (2012). A crosscultural approach to understanding entrepreneurial intention. Journal of Career Development, 39(2), 162-185.doi:10.1177/0894845310384481

27. Morris, M. H., Webb, J. W., Fu, J., \& Singhal, S. (2013). A competency-based perspective on entrepreneurship education: Conceptual and empirical insights. Journal of Small BusinessManagement, 51(3), 352-369. doi:10.1111/jsbm.2013.51.issue-3

28. Pascarella, E. T., \& Terenzini, P. T. (1983). Predicting voluntary freshman year persistence/ withdrawal behavior in a residential university: A path analytic validation of Tinto's model. Journal of Educational Psycholojy, 75, 2 15-226.

29. Pascarella, E. T., \& Terenzini, P. T. (1991). How college affects students. San Francisco: JosseyBass. 
30. Peng, S. S., \& Hall, S. T. (1995). Understanding racial-ethnic differences in secondaryschool science and mathematics achievement (NCES No. 95710). Washington DC: U.S. Department of Education.

31. Phillips, D. P. (2013). Social entrepreneurship as change agent in the academy. In L. Book \& D. P. Phillips (Eds.), Creativity and entrepreneurship: Changing currents in education and public life (pp. 36-51). Northampton, MA: Edward Elgar.

32. Poysa-Tarhonnen, J., Elen, J., \& Tarhonen, P. (2016). Student teams' development over time: Tracing the relationship between the quality of communication and teams' performance. Higher Education Research \& Development, 35, 787-799. doi:10.1080/07294360.2015.1137887

33. Roberts, G. A. (2007). The effect of extracurricular activity participation in the relationship between parent involvement and academic performance in a sample of third grade children. Retrieved from https:/www.lib.utexas.edu/etd/d/2007/ robertsg11186/robertsg 11186.pdf

34. Selznick, B. S, \& Mayhew, M. J. (2018). Measuring undergraduates' innovation capacities. Research in Higher Education, 59(6), 744-764. doi: 10.1007/s11162-017-9486-7

35. Shane, S. A. (2003). A general theory of entrepreneurship: The individual-opportunity nexus. Northampton, MA: Elgar.

36. Shumox, L., \& Lomax, R. (2001). Parental efficacy: Predictor of parenting behavior and adolescent outcomes. Parenting, 2(2), 127-150.

37. Souitaris, V., Zerbinati, S., \& Al-Laham, A. (2007). Do entrepreneurship programmes raise entrepreneurial intention of science and engineering students? The effect of learning, inspiration and resources. Journal of Business Venturing, 22, 566-591. doi:10.1016/j. jbusvent.2006.05.002

38. Stage, F. K. (1989). Motivation, academic and social integration and early dropout. American Educational Research Journal, 26, 385-402.

39. Tinto, V. (1975). Dropout from higher education: A theoretical synthesis of recent research. Review of Educational Research, 45, 89-125.

40. Wagner, T. (2012). Creating innovators: The making of young people who will change the world. New York, NY: Scribner.

41. Walberg, H. J. (1981). A psychological theory of educational productivity. In F. H. Farley \& N. U. Gordon (Eds.), Psychology and education. Berkeley, CA: McCutchan.

42. Winkel, D., Vanevenhoven, J., Drago, W. A., \& Clements, C. (2013). The structure and scope of entrepreneurship programs in higher education around the world. Journal of Entrepreneurship Education, 16, 15-29.

43. Zhao, H., Seibert, S. E., \& Hills, G. E. (2005). The mediating role of self-efficacy in the development of entrepreneurial intentions. Journal of Applied Psychology, 90, 1265-1272. doi:10.1037/0021-9010.90.6.1265 